\title{
Usage analysis of the Nursing Activities Score in two Spanish ICUS
}

\author{
ANÁLISE DA UTILIZAÇÃO DA ESCALA NURSING ACTIVITIES SCORE EM DUAS UCIS \\ ESPANHOLAS
}

\section{ANÁLISIS DE LA UTILIZACIÓN DE LA ESCALA NURSING ACTIVITIES SCORE EN DOS UCIS ESPAÑOLAS}

\author{
Francisco Javier Carmona-Monge ${ }^{1}$, Ikerne Uria Uranga ${ }^{2}$, Sonia García Gómez ${ }^{3}$, Cristina Quirós \\ Herranz $^{4}$, Maitane Bergaretxe Bengoetxea ${ }^{5}$, Goiatz Etxabe Unanue ${ }^{6}$, Alazne Iribarren Martin ${ }^{7}$, \\ Maialen Echepetelecu Hernando ${ }^{8}$, Erika Badiola Saralegui ${ }^{9}$, Miren Auzmendi Irazoqui ${ }^{10}$
}

\begin{abstract}
The aim of the present study is to analyze the differences in NAS scoring in two Spanish critical care units. Prospective study performed in two polyvalent Spanish ICUs during the months of October and November 2011. Data regarding nursing workload was collected daily in both units for all the patients admitted in the ICU during the study period through the Nursing Activities Score (NAS). Data from 103 patients was collected obtaining 941 NAS measures. Statistically significant differences were found in the collection of the following items: monitoring and titration, hygiene procedures, mobilization and positioning, administrative and managerial tasks and left atrium monitoring $(p<.001)$. Using standardized instruments to measure workload is important in order to be able to compare between different ICU. The NAS scale has several items with an important subjective assessment component. It is important to establish unified assessment criteria so comparisons between units can be made.
\end{abstract}

\section{DESCRIPTORS}

Workload

Intensive care

Critical care

Nursing, staff

\section{RESUMO}

Estudo prospetivo cujo objetivo foi analisar as diferenças no preenchimento da escala Nursing Activities Score (NAS) em duas UTI polivalentes de dois hospitais espanhóis. Dados relativos internados nas unidades durante o período de outubro a novembro de 2011. Os dados recolhidos de 103 pacientes produziram 941 medições na escala NAS. Diferenças significativas foram encontradas nos itens: monitoramento, procedimentos de higiene, mobilização e posicionamento, atividades administrativas e monitoramento auricular à esquerda $(p<$ $0,001)$. Conclui-se que o uso de instrumentos padronizados é essencial quando se compara a carga de trabalho em unidades diferentes. A escala apresenta itens com uma componente de avaliação subjetiva, sendo por isso importante a unificação de critérios para a comparação de resultados entre diferentes unidades.

\author{
DESCRITORES \\ Carga de trabalho \\ Terapia intensiva \\ Cuidados críticos \\ Equipe de enfermagem
}

\section{RESUMEN}

Estudio prospectivo cuyo objetivo fue analizar las diferencias en el llenado de la escala Nursing Activities Score (NAS) en dos UCls polivalentes de dos hospitales españoles. Datos relacionados a la carga de trabajo se recogieron diariamente, mediante la escala para los pacientes internados en las unidades durante el periodo de octubre a noviembre del 2011. Se recogieron datos de 103 pacientes obteniéndose un total de 941 medidas de la escala NAS. Diferencias significativas se encontraron en los ítems: monitorización, procedimientos de higiene, movilización y posición, tareas administrativas y monitorización de la aurícula izquierda $(p<0.001)$. Se concluyó que el empleo de instrumentos estandarizados es fundamental para poder comparar la carga de trabajo en diferentes unidades. La escala presenta ítems con un componente de valoración subjetiva, siendo importante la unificación de criterios para poder comparar los resultados entre las distintas unidades.

\section{DESCRIPTORES \\ Carga de trabajo \\ Cuidados intensivos \\ Cuidados críticos \\ Personal de enfermería}

\footnotetext{
${ }^{1}$ Nurse. Critical Care Unit, University Hospital Alcorcón Foundation, Madrid, Spain. javier.carmona@urjc.es ${ }^{2}$ Nurse. Intensive Care Unit, University Hospital Donostia, Guipúzcoa, Spain. ${ }^{3}$ Nurse. Critical Care Unit, University Hospital Alcorcón Foundation, Madrid, Spain. ${ }^{4}$ Nurse. Critical Care Unit, University Hospital Alcorcón Foundation, Madrid, Spain. ${ }^{5}$ Nurse. Intensive Care Unit, University Hospital Donostia, Guipúzcoa, Spain. ${ }^{6}$ Nurse. Intensive Care Unit, University Hospital Donostia, Guipúzcoa, Spain. ${ }^{7}$ Nurse. Intensive Care Unit, University Hospital Donostia, Guipúzcoa, Spain. ${ }^{8}$ Nurse. Intensive Care Unit, University Hospital Donostia, Guipúzcoa, Spain. ${ }^{9}$ Nurse. Intensive Care Unit, University Hospital Donostia, Guipúzcoa, Spain. ${ }^{10}$ Nurse. Intensive Care Unit,
} University Hospital Donostia, Guipúzcoa, Spain.

$\begin{aligned} & \begin{array}{r}\text { Rev Esc Enferm USP } \\ 2013 ; 47(3): 1106-13 \\ \text { www.ee.usp.br/reeusp/ }\end{array} \text { Received: 06/26/2012 } \\ & \text { Approved: 06/13/2013 }\end{aligned}$




\section{INTRODUCTION}

Intensive Care Units (ICUs) admit critical patients whose conditions are of vital importance. However, not all admitted patients present conditions of the same clinical severity; hence, they require different attention. Consequently, the personnel of an ICU treat a diverse group of patients in terms of pathological features, condition severity and required nursing assistance ${ }^{(1)}$.

In each particular unit, it is necessary to identify the characteristics of the admitted patients to compare different patient groups and analyze the nursing workload and assistance required to attend to the different conditions. Workload indicators have become necessary to guarantee patient assistance, improve ICU quality and balance its effectiveness ${ }^{(2)}$. Moreover, we have to consider that severity level and required workload fluctuations may occur during the stay of a patient in the $\mathrm{ICU}^{(1)}$; in this regard, a working group ${ }^{(3)}$ found that patients with more severe conditions required greater nursing care support.

In recent years, hospital healthcare proximity, specifically in ICUs, has gained special attention. Healthcare personnel should provide emotional support and all necessary information to patients and their relatives. Thus, a lack of quantity and quality in nursing personnel directly jeopardizes hospital healthcare. Moreover, this insufficiency could legally compromise the institution because of excessive nursing workload and healthcare quality deficits ${ }^{(4)}$.

Nursing workload evaluation scores permit the classification of patients based on the assistance needed. In this way, the scores favor quality control and results comparison between units with different characteristics. These scores objectively reflect nursing workload and personnel-specific needs in a determined unit, leading to adequate nursing personnel ${ }^{(1)}$. Different organizations have highlighted the significance of accurate personnel allocation not only to increase patient security but also to decrease healthcare-associated complications ${ }^{(5-6)}$ such as nosocomial infections ${ }^{(7-8)}$, post-operative complications $^{(9-10)}$, pressure ulcers ${ }^{(11)}$, extubations and reintubations $^{(10)}$, and mortality ${ }^{(12)}$. Moreover, adequate nursing personnel allocation is important for the proper adjustment of medical costs for patient assistance. Studies have compared NAS points to those obtained by other ICU workload evaluation scores such as the NEMS or TISS-28. They have found that the NAS offers greater accuracy in workload evaluation ${ }^{(13)}$.

The first score used to evaluate nursing workload was based on items determining patient condition severity and focused on the interventions or treatments received. This score was named the Therapeutic Intervention
Scoring System (TISS) $^{(14)}$. The TISS allows the specification of nursing personnel workload and needs, but it is not widely used due to its complexity and the time required to complete its 76 activities ${ }^{(14)}$. Efforts were made to simplify data collection, and the number of interventions was reduced to 28 (TISS-28), maintaining only those that, after statistical analysis, showed the greatest contributions to the total score ${ }^{(15)}$.

In 1994, the Foundation for Research in Intensive Care in Europe (FRICE) developed and validated a new score named the Nine Equivalents of Nursing Manpower Use Score (NEMS). The NEMS achieved an unbiased and simplified evaluation of the healthcare effort through the analysis of only nine parameters ${ }^{(14)}$. The NEMS was developed from the TISS-28 by selecting those items with major utility in patient stratification. This explains why the NEMS remains an indirect measurement of nursing workload. It evaluates only patient therapeutic intervention activities, leaving aside the huge amount of nursing activities not directly linked to these interventions.

The Nursing Activities Score (NAS) was developed to quantitatively assess this kind of nursing workload. The NAS aims to evaluate not only those nursing activities related to the severity of illness and therapeutic intervention but also the patient assistance activities that are independent of illness severity ${ }^{(14)}$. This score was developed by Dr. Miranda and members of the TISS Working Group. The design of the NAS was based on the identification of nursing activities that better describe the workload in an ICU. A specific score is attributed according to the time consumption of each activity to appropriately attend to patient needs. The NAS does not relate to the severity of illness, and its main advantage is its accuracy in calculating the time consumption of healthcare activities, defining its scores to the $81 \%$ of total nursing time, thus increasing its reliability and validity ${ }^{(15-16)}$.

The NAS was developed to overcome existing problems with previous scores, such as a medical design not oriented to nursing (TISS)(17), a time-consuming completion and a lack of adjustment in personnel calculation (NE$M S)^{(17-19)}$ and a continuous need for updating. NAS items were selected and defined by consensus in a multicentric study between different groups of experts ( 15 doctors and 10 nurses of intensive care units). Twenty-three routine nursing activities were included. The average time for each nursing activity was estimated and this parameter was used to allocate the weight of each item composing the new scoring system.

The NAS has been used in different national and international studies to calculate nursing workloads in ICUs, including those in Brazil, Spain and Norway. The 
NAS has also been used to establish adequate allocation of available resources to personnel needs ${ }^{(2,20-26)}$. Although there has been almost a decade since the first NAS publication, its usage as a tool to measure ICU nursing workload is still relatively new in the national and international literature ${ }^{(27)}$.

The NAS was originally developed in English ${ }^{(15)}$ and has been translated to Spanish by Arias-Rivera et al. The NAS was adapted for its application to shift work following the recommendations of the research group of Miranda et al. ${ }^{(28)}$. In 2004, Queijo et al. ${ }^{(27)}$ published an NAS adaptation and its following intercultural validation in Portuguese. The results showed that the NAS is a valid and reliable tool to measure nursing workload in Brazilian ICUs ${ }^{(27)}$.

A small user guide supplements the NAS to guarantee homogeneity in the registration of different items. However, despite these guidelines, the subjective component could hinder some item scoring, resulting in differences in NAS points. These differences are not because of patient characteristics but are due to altered interpretations by healthcare professionals. The results of Queijo et al.(27) have indicated nursing workload variability between different Brazilian studies.

In Brazil, after the introduction of the NAS Portuguese translation, some problems were observed in its application by ICU nursing staffs ${ }^{(29)}$. The major difficulties were related to a lack of clarity in the operational explanations of several items. A lack of ICU nursing registration was observed specifically in relation to items 1 (monitoring and serotherapy), 4 (hygiene procedures), 6 (mobilization and positioning), 7 (support and assistance to the patient's companions) and 8 (administrative and management tasks). Moreover, the NAS considers and recommends an 8-hour work shift, while in the majority of Brazilian ICUs, nursing personnel work in 6 - or 12 -hour shifts. These discrepancies motivated Gonçalves et al. ${ }^{(29)}$ to develop a proposal for NAS functional application. They considered providing guidelines for the problematic items and ensuring that all nursing personnel from the same ICU systematically collect the data. To use this system as a tool for personnel allocation, it is important to analyze possible score variations produced independently from the patient's real condition. Moreover, it is important to ensure that the difficulties in determined items in Portuguese were also found in other languages.

The extended use of tools for the unbiased measure of nursing workload in ICUs will favor a better adjustment of the available resources to the real needs of the patients ${ }^{(30)}$. For this reason, the aim of the present work is to analyze the nursing workload in two ICUs of two Spanish hospitals and the existing differences in the completion of controversial items. This work aims at applying appropriate corrective measures to obtain a precise calculation of nursing workload.

\section{METHOD}

\section{Design and site of study}

A descriptive, prospective study was performed during 47 days between October and November 2011. The study was carried out in two Spanish University Hospitals (one in the Community of Madrid [H1] and the other in the Basque Country [H2]). Data collection was performed in the adult intensive care units of these centers. The $\mathrm{H} 1$ unit was comprised of 12 beds with patients admitted because of medical pathologies. The nurse/patient ratio in all shifts was 1:2 or 1:3. Nursing personnel worked in a 12-hour shift. The $\mathrm{H} 2$ unit included 10 beds and also admitted patients with fundamental medical pathologies. The nurse/ patient ratio was $1: 2$ or $1: 3$. In this unit, there were morning, afternoon and night working shifts ( 7 hours in day shifts and 10 hours in night shifts).

\section{Participants}

Patients admitted to the ICUs who were older than 18 years old were included in the study. A total of 103 patients, 66 from unit $\mathrm{H} 1$ and 37 from unit $\mathrm{H} 2$, constituted the final sample size.

\section{Data collection}

Demographic and clinical data related to the admitted patients of both units were collected. Moreover, unit workload for each patient was collected daily through the NAS. Data registration was performed at 7 hours in the $\mathrm{H} 1$ unit and at 21 hours in the $\mathrm{H} 2$ unit. In both cases, information corresponding to the 24 hours before admission was also collected through the nursing chart.

The NAS is comprised of 23 items. Each item has an assigned weight, which evaluates the time required to perform the nursing activities. This weight represents the estimated time percentage that nursing personnel dedicate to activities included in the NAS tool (during 24 hours). The sum of the weights of the individual items reflects ICU nursing activities in a determined day. The maximum NAS score is 178.7 points and the minimum is 0 points. A fulltime working nurse during 24 hours can handle a workload of 100 points.

This project was approved by the Ethical and Research Committees of both centers (H1 project $11 / 74 ; \mathrm{H} 2$ project 8/2011).

\section{Statistical Analysis}

The Statistical Package for the Social Sciences (SPSS), version 18.0 for Windows, was used for statistical analysis. Data are presented as the mean with a confidence interval of $95 \%$.

Student's t-test was used to analyze differences between continuous variables. For categorical variables, the Chi-squared test was used. Effect size was calculated by

Rev Esc Enferm USP
$2013 ; 47(3): 1106-13$$\quad \begin{aligned} & \text { Usage analysis of the Nursing Activities score in two } \\ & \text { Spanish ICUS } \\ & \text { Carmona-Monge FJ, Uranga IU, Gómez SG, Herranz CQ, Bengoetxea } \\ & \text { MB, Unanue GE, Martin Al, Hernando MA, Saralegui EB, Irazoqui MA }\end{aligned}$


Cohen's $d$ test. $P<0.05$ was considered statistically significant (bilaterally).

\section{RESULTS}

\section{Sample characteristics}

The main reasons for admission were coronary pathologies, constituting more than half of the patients admitted during the study $(52.3 \%)$, and medical-type pathologies $(40.5 \%)$, in units $\mathrm{H} 1$ and $\mathrm{H} 2$, respectively. In both cases, there were more men than women. No statistically significant differences were found between the two units in regard to mean age, mortality rate and average stay in the unit (see Table 1).

In unit $\mathrm{H} 1$, a mean of 12.17 patients were admitted daily $(95 \% \mathrm{Cl}, 11.79-12.55)$ with a mean daily admissions and dismissals of 1.17. In unit $\mathrm{H} 2$, the mean daily-admitted patient number was $8.09(95 \% \mathrm{Cl}, 7.81-8.36)$ with a mean daily admissions and dismissals of approximately 0.5 (Table 1).

Table 1 - Patients characteristics admitted in both units and workload during the study

\begin{tabular}{|c|c|c|c|c|c|c|}
\hline & & H1 & & H2 & Chi & \\
\hline & $\mathbf{n}$ & $\%$ & $\mathbf{n}$ & $\%$ & squared & $\mathbf{p}$ \\
\hline Reason of admission & & & & & 42.797 & $<.001$ \\
\hline Cardiologic & 34 & 52.3 & 3 & 8.1 & & \\
\hline Medical & 30 & 42.2 & 15 & 40.5 & & \\
\hline Postsurgical & 1 & 1.5 & 13 & 35.1 & & \\
\hline Polytraumatized & 0 & 0.0 & 6 & 16.2 & & \\
\hline Sex (men) & 23 & 62.2 & 37 & 56.9 & 0.267 & .605 \\
\hline \multirow[t]{2}{*}{ Mortality } & 7 & 10.8 & 5 & 13.5 & 0.171 & .679 \\
\hline & $\mathbf{M}$ & IC $95 \%$ & $\mathbf{M}$ & IC $95 \%$ & $\mathbf{T}$ & $\mathbf{p}$ \\
\hline Age & 65.08 & $60.84-69.32$ & 61.84 & $56.44-67.24$ & 0.937 & .351 \\
\hline ICU stay length & 12.79 & $5.09-20.49$ & 13.17 & $9.60-16.73$ & 0.071 & .944 \\
\hline Daily patients & 12.17 & $11.79-12.55$ & 8.09 & $7.81-8.36$ & & \\
\hline Dismissals & 1.17 & $0.93-1.41$ & 0.38 & $0.18-0.58$ & & \\
\hline NAS global & 633.97 & $608.61-659.33$ & 467.37 & $447.49-487.23$ & & \\
\hline NAS nurse & 53.66 & $51.81-55.52$ & 55.81 & $54.08-57.54$ & 9.426 & $<.001$ \\
\hline NAS patient & 122.82 & $117.68-127.96$ & 93.39 & $89.77-97.01$ & 1.702 & .092 \\
\hline
\end{tabular}

\section{Workload in both units}

Table 1 shows global workload, nursing workload and workload per patient data for each unit. No significant differences were found in the daily mean workload per patient between the two units $(t(92)=1.702 ; p=$ 0.092). However, in both units, there were statistically significant differences related to nursing workload. $\mathrm{H} 1$ showed higher differences with 122.82 NAS points for each nurse, whereas in $\mathrm{H} 2$ there were 93.39 NAS points $(t(92)=9.426 ; p<0.001 ; d=1.95)$.

\section{Items usage analysis}

The following items, included in the score, were analyzed in both units: monitoring tasks (item 1), hygiene procedures (item 4), mobilization (item 6), support and attendance to patient companions (item 7), administrative tasks (item 8 ) and left atrium monitoring (item 14) (Table 2 shows these items, with the different patient classification options and the assigned weight of the available options). Statistically significant differences were found between the units for the completion of these items (Chart 1 and Table 2).
In the case of monitoring tasks $\left(x^{2}=194.641 ; p<.001\right)$, in unit $\mathrm{H} 1$, there were more registries related to basic monitoring and monitoring tasks with more than a four-hour duration, whereas in the $\mathrm{H} 2$ unit, there was a significantly higher number of registries pertaining to two-hour duration monitoring tasks.

In the hygiene task item $\left(x^{2}=210.120 ; p<.001\right)$, there were more registries in unit $\mathrm{H} 1$ corresponding to procedures performed once a day and more than three times a day. In unit $\mathrm{H} 2$, there were more registries with the option of performing these tasks three times per day. Concerning mobilization and positioning $\left(x^{2}=\right.$ $10.741 ; p=.005)$, the $\mathrm{H} 1$ unit recorded more registries in the performance of such tasks more than three times per day and the involvement of three or more nurses (without noting the frequency), whereas in $\mathrm{H} 2$, the greater number of registries was recorded in cases of performing such tasks up to three times per day.

In the $\mathrm{H} 1$ unit, a larger number of registries were described as routine communication attendance to patient relatives $\left(x^{2}=238.201 ; p<.001\right)$, whereas in the $\mathrm{H} 2$ unit, more registries were recorded as minimum one-hour dedication to relatives in attendance. 
Concerning management and administrative tasks $\left(x^{2}=\right.$ 29.772; $p<.001)$, in $\mathrm{H} 1$ there were more than two hours of dedication(including patientsadmissionand dismissaltasks).In $\mathrm{H} 2$, there were more registries of routine administration tasks.

Chart 1 - Details of items with completion differences between both units.

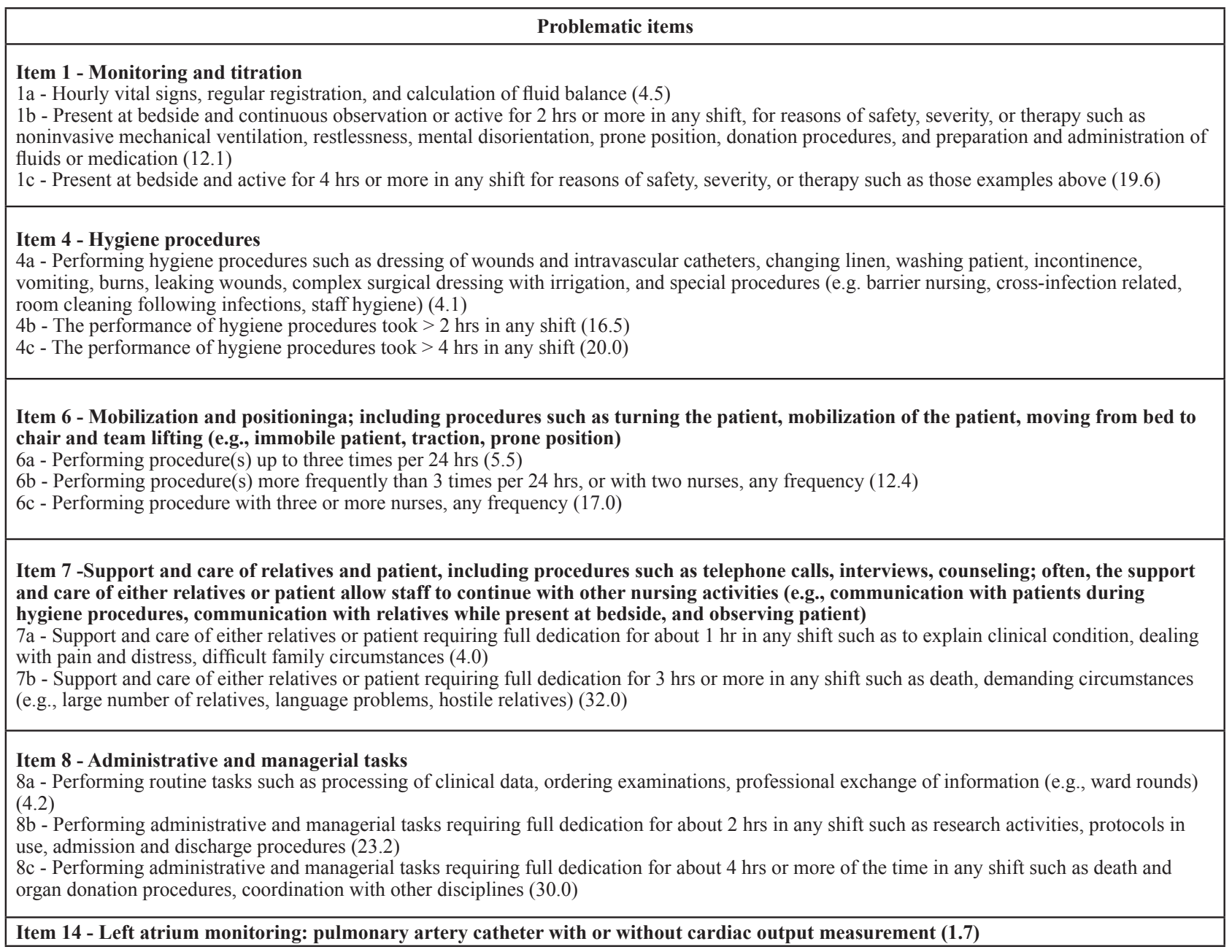

Table 2 - NAS item usage analysis in both ICUs during the study

\begin{tabular}{|c|c|c|c|c|c|c|c|}
\hline & & \multicolumn{2}{|c|}{ H1 } & \multicolumn{2}{|c|}{ H2 } & \multicolumn{2}{|l|}{ Chi } \\
\hline & & $\mathbf{n}$ & $\%$ & $\mathbf{n}$ & $\%$ & square & $\mathbf{p}$ \\
\hline \multirow{3}{*}{ Monitoring } & $\mathrm{a}$ & 497 & 85.1 & 157 & 44.0 & \multirow{3}{*}{194.641} & \multirow{3}{*}{$<.001$} \\
\hline & $\mathrm{b}$ & 49 & 8.4 & 163 & 45.7 & & \\
\hline & $\mathrm{c}$ & 38 & 6.5 & 37 & 10.4 & & \\
\hline Laboratory & & 580 & 99.3 & 339 & 95.0 & & \\
\hline Drugs & & 584 & 100.0 & 356 & 99.7 & & \\
\hline \multirow{3}{*}{ Hygiene } & $\mathrm{a}$ & 534 & 91.4 & 219 & 61.3 & \multirow{3}{*}{210.210} & \multirow{3}{*}{$<.001$} \\
\hline & $\mathrm{b}$ & 11 & 1.9 & 130 & 36.4 & & \\
\hline & $\mathrm{c}$ & 39 & 6.7 & 8 & 2.2 & & \\
\hline Drains & & 111 & 19.0 & 182 & 51.0 & & \\
\hline \multirow{3}{*}{ Mobilization } & $\mathrm{a}$ & 215 & 36.8 & 173 & 48.5 & \multirow{3}{*}{10.741} & \multirow{3}{*}{.005} \\
\hline & $\mathrm{b}$ & 336 & 57.5 & 174 & 48.7 & & \\
\hline & $\mathrm{c}$ & 33 & 5.7 & 10 & 2.8 & & \\
\hline \multirow{2}{*}{ Relatives } & $\mathrm{a}$ & 575 & 98.5 & 216 & 60.5 & \multirow{2}{*}{238.201} & \multirow{2}{*}{$<.001$} \\
\hline & $\mathrm{b}$ & 1 & 0.2 & 18 & 5.0 & & \\
\hline \multirow{2}{*}{ Administrative } & $\mathrm{a}$ & 530 & 90.8 & 355 & 99.5 & \multirow{2}{*}{29.776} & \multirow{2}{*}{$<.001$} \\
\hline & $\mathrm{b}$ & 54 & 9.2 & 2 & 0.5 & & \\
\hline
\end{tabular}




\begin{tabular}{|c|c|c|c|c|c|c|}
\hline & \multicolumn{2}{|c|}{ H1 } & \multicolumn{2}{|c|}{$\mathrm{H2}$} & \multicolumn{2}{|l|}{ Chi } \\
\hline & $\mathbf{n}$ & $\%$ & $\mathbf{n}$ & $\%$ & square & $\mathbf{p}$ \\
\hline Ventilatory support & 571 & 97.8 & 308 & 86.3 & & \\
\hline Airway care & 384 & 65.8 & 178 & 49.9 & & \\
\hline Ventilation treatment & 414 & 70.9 & 270 & 75.6 & & \\
\hline Vasoactive medications & 81 & 13.9 & 114 & 31.9 & & \\
\hline Fluid replacement & 2 & 0.3 & 2 & 0.6 & & \\
\hline Left atrium monitoring & 28 & 4.8 & 8 & 2.2 & 3.927 & .032 \\
\hline $\mathrm{CPR}$ & 1 & 0.2 & 1 & 0.3 & & \\
\hline Renal replacement therapy & 49 & 8.4 & 49 & 13.7 & & \\
\hline Diuresis & 504 & 86.3 & 356 & 99.7 & & \\
\hline Intracranial pressure & 0 & 0.0 & 53 & 14.8 & & \\
\hline Metabolic & 7 & 1.2 & 13 & 3.6 & & \\
\hline Total parenteral nutrition & 47 & 8.0 & 65 & 18.2 & & \\
\hline Enteral nutrition & 281 & 48.1 & 169 & 47.3 & & \\
\hline ICU interventions & 38 & 6.5 & 20 & 5.6 & & \\
\hline Extra ICU interventions & 32 & 5.5 & 33 & 9.2 & & \\
\hline
\end{tabular}

Concerning the left atrium monitoring item $\left(x^{2}=3.927\right.$; $p=0.048)$, unit $\mathrm{H} 1$ recorded positive points in more patients than did unit $\mathrm{H} 2$.

\section{DISCUSSION}

In intensive care units, adequate nursing personnel allocation is essential to guarantee the healthcare quality required for admitted patients, to increase their security during their stay and, at the same time, to reduce the appearance of side effects. Nursing workload evaluation tools are fundamental to accurately evaluate the workload and adjust the resources to provide what the patients need.

There are several available evaluation systems that have been evolving over the years. Initially, these tools assessed nursing activities related to medical treatment applied to patients. Recently, they have evolved into tools for the assessment of the real nursing assistance workload rather than only inter-dependent or collaborative nursing activities. The NAS in particular is a reliable tool for assessing nursing workload in intensive care units. It is used in many countries and institutions and the publications applying this score for the analysis of workload continuously grow ${ }^{(2,21-26)}$.

However, despite the score's accuracy when assessing nursing workload, there are items that presented certain difficulties at the time of their evaluation. Gonçalves et al. (29) identified difficulties in the application of certain items when the tool was validated in Portuguese. They noted the necessity to elaborate additional instructions for certain items. However, no relative references were found concerning these difficulties in any other country. In our work, we applied this score to Spanish ICUs. We found significant differences in the completion of items $1,4,6,7,8$ and 14 . These differences were not justified by patient characteristics. It is possible that these differences exist because of the different ways the ite$\mathrm{ms}$ were assessed in each of the participating units. This is a major problem because the existence of differences is based on biased perceptions that could reduce score efficacy not only for personnel allocations but also for comparison establishment between different units. To date, no study exists that performs these comparisons between different units. NAS guidelines assume that registrations are identical between different ICUs and nursing personnel. The aim of the present work is to demonstrate that this cannot be a default situation. It has been shown that different professionals in different units register differently the score's various items.

A review of the most controversial items is necessary. Moreover, the development of more detailed and complete instructions to guarantee homogeneity in registration between different units is also recommended. It is fundamental to establish a consensus concerning what activities and situations should be registered in each of these items. In that way, accurate personnel needs and results comparisons between different institutions and countries could be established.

This study has limitations. First, this study was developed in two medical ICUs. Therefore, there are no data concerning post-surgical patients. This group of patients has been highlighted in other studies because of the increased workload required during their first days of stay in the unit. Moreover, special characteristics of the Spanish healthcare system (ICU workload organization, professionals working at the unit, etc.) should be considered because they might have a significant effect on results. Study patient recruitment was not randomized. All patients admitted in the units during the study were included during a limited time. In future studies, it would be interesting to include an additional variable indicating the severity of the patients' conditions (SAPS II, APACHE II, etc.). This could allow a comparison with other studies performed on the same subject. 


\section{CONCLUSION}

The NAS is a standardized tool for the assessment of workload in intensive care units worldwide. It has an undoubted utility for the establishment of nursing necessities in an ICU. However, as previously mentioned in

\section{REFERENCES}

1. Robas Gomez A, Romero Romero V, Garcia Garcia R, Sanchez Martin R, Cabestrero Alonso D. ¿Puede ayudar la escala NEMS a clasificar de manera homogénea a los pacientes que ingresan en Cuidados Intensivos? Enferm Intensiva. 2007;18(2):70-7.

2. Padilha KG, Sousa RMC, Garcia PC, Bento ST, Finardi EM, Hatarashi RH.K. Nursing workload and staff allocation in an intensive care unit: A pilot study according to Nursing Activities Score (NAS). Intensiv Crit Car Nurs. 2010;26(2):108-13.

3. Balsanelli AP, Zanei SS, Whitaker IY. Carga de trabalho de enfermagem e sua relação com a gravidade dos pacientes cirúrgicos em UTI. Acta Paul Enferm. 2006;19(1):16-20.

4. Conishi RM, Gaidzinski RR. Nursing Activities Score (NAS) como instrumento para medir carga de trabalho de enfermagem em UTI adulto. Rev Esc Enferm USP. 2007; 41(3):346-54.

5. Podgorny KL. A performance improvement perspective. Excell Nurs Knowl. 2004; 1(3):1-7.

6. British Association of Critical Care Nurses. BACCN Standards for nurse staffing in Critical Care. Newcastle upon Tyne: British Association of Critical Care Nurses; 2010.

7. Hugonnet S, Chevrolet JC, Pittet D. The effect of workload on infection risk in critically ill patients. Crit Care Med. 2007;35(1):76-81.

8. Hugonnet S, Uckay I, Pittet D. Staffing level: a determinant of late-onset ventilator-associated pneumonia. Crit Care. 2007;11(4):R80.

9. Dang D, Johantgen ME, Pronovost PJ, Jenckes MW, Bass EB. Postoperative complications: does intensive care unit staff nursing make a difference? Heart Lung. 2002; 31(3):219-28.

10. Penoyer DA. Nurse staffing and patient outcomes in critical care: a concise review. Crit Care Med. 2010;38(7):1521-8.

11. Lake ET, Cheung RB. Are patient falls and pressure ulcers sensitive to nurse staffing? West J Nurs Res. 2006;28(6):654-77.

12. Cho SH, Ketefian S, Barkauskas VH, Smith DG. The effects of nurse staffing on adverse events, morbidity, mortality, and medical costs. Nurs Res. 2003;52(2):71-9. several works, there are difficulties in the completion of some of its items. For that reason, it is necessary to continue to explore the difficulties derived from its use and analyze the most controversial items to standardize its completion, facilitate its use and enable the possibility of comparing results between different intensive care units.

13. Padilha KG, Sousa RMC, Kimura M, Miyadahira AM, Cruz DALM, Vattimo MF, et al. Nursing workload in intensive care units: a study using the Therapeutic Intervention Scoring System-28 (TISS-28). Intensive Crit Care Nurs. 2007;23(3):162-9.

14. Bernat-Adell A, Abizanda-Campos R, Cubedo-Rey M, Quintana-Bellmunt J, Sanahuja-Rochera E, Sanchís-Muñoz J, et al. Nursing Activities Score (NAS): nuestra experiencia con un sistema de cómputo basado en tiempo. Enferm Intensiva. 2005;16(4):164-73.

15. Miranda DR, Nap R, de Riijk A, Schaufeli W, lapichino G; TISS Working Group. Therapeutic Intervention Scoring System. Nursing activities score. Crit Care Med. 2003; 31(2):374-82.

16. Subirana-Casacuberta M, Solà-Arnau I. Instrumentos basados en medidas directas para UCI II: NAS (Nursing Activities Score). Metas Enferm. 2006;9(10):67-71.

17. Subirana-Casacuberta M, Solà-Arnau I. Instrumentos basados en medidas directas para UCI: TISS y NEMS. Metas Enferm. 2007;10(1):15-20.

18. Reis Miranda D, Moreno R, lapichino G. Nine equivalents of nursing manpower use core (NEMS). Intensive Care Med. 1997;23(7):760-5.

19. Miranda DR, Nap R, de Rijk A, Schaufeli W, lapichino G. Nursing activities score. Crit Care Med. 2003; 31(2):374-82.

20. Lundgrén-Laine $H$, Suominen $T$. Nursing intensity and patient classification at an adult Intensive Care Unit (ICU). Intensive Crit Care Nurs. 2007;23(2):97-103.

21. Padilha KG, Sousa RMC, Queijo AF, Mendes AM, Reis Miranda $D$. Nursing Activities Score in the intensive care unit: analysis of the related factors. Intensive Crit Care Nurs. 2008;24(3):197-204.

22. Conishy RMY, Gaidzinski RR. Evaluation of the Nursing Activities Score as a nursing workload measurement tool in an adult ICU. Rv Esc Enferm USP. 2007;41(3):346-54.

23. Ducci AJ, Padilha KG. Nursing Activities Score: a comparative study about retrospective and prospective applications in intensive care units. Acta Paul Enferm. 2008;21(4):581-7. 
24. Rollán Rodrígues G, Carmona Monge FJ, Quirós Herranz C, Cerrillo González I, Jara Pérez A, García Gómez S, et al. Escalas de medida de carga de trabajo de enfermería en unidades de cuidados críticos: correlación entre NAS y NEMS. NURE Inv [Internet]. 2011 [citado 2012 mayo 22];8(55). Disponible en: http://www.fuden.es/FICHEROS_ADMINISTRADOR/INV_NURE/NURE55_proyecto_escalas19102011134523.pdf

25. Jara Pérez A, Carmona Monge FJ, Martínez Lareo M, Quirós Herranz C, Rollán Rodrígues G, Cerrillo González I. Carga de trabajo de enfermería en una unidad de cuidados intensivos y su relación con la incidencia de infecciones nosocomiales. NURE Inv [Internet]. 2011 [citado 2012 mayo 22];8(51). Disponible en: http://www.nureinvestigacion.es/FICHEROS_ADMINISTRADOR/INV_NURE/NURE51_proyecto_cargatr.pdf

26. Stafseth SK, Solms D, Bredal IS. The characterisation of workloads and nursing staff allocation in intensive care units: a descriptive study using the Nursing Activities Score for the first time in Norway. Intensive Crit Care Nurs. 2011;27(5):290-4.
27. Queijo AF, Padilha KG. Nursing Activities Score (NAS): crosscultural adaptation and validation to Portuguese language. Rev Esc Enferm USP [Internet]. 2009 [cited 2012 May 17];43(n.spe):1001-8. Available from: http://www.scielo.br/ pdf/reeusp/ v43nspe/en_a04v43ns.pdf

28. Arias-Rivera S, Sánchez-Sánchez MM, Fraile-Gamo MP, Patiño-Freire S, Pinto-Rodríguez V, Conde-Alonso MP, ET AL. Adaptación transcultural al castellano del Nursing Activities Score. Enferm Intensiva. 2012;24(1):12-22.

29. Gonçalves LA, Padilha KG, Sousa RMC. Nursing Activities Score (NAS): a proposal for practical application in intensive care units. Intensive Crit Care Nurs. 2007;23(6):355-61.

30. Ducci AJ, Zanel SSV, Whitaker IY. Nursing workload to verify nurse/patient ratio in a cardiology ICU. Rev Esc Enferm USP [Internet]. 2008 [cited 2012 May 23];42(4):673-80. Available from: http://www.scielo.br/pdf/reeusp/ v42n4/ en_v42n4a08.pdf

\section{Acknowledgments}

This work was partially funded by Health Institute Carlos III (Instituto de Salud Carlos III) through grants of the Health Research Funds [Fondo de Investigaciones Sanitarias, FIS] (project PI10/02198). 